\title{
Compilation of ozonesonde profiles from the Antarctic Georg-Forster-Station from 1985 to 1992
}

\author{
G. König-Langlo and H. Gernandt \\ Alfred Wegener Institute for Polar and Marine Research, Bussestraße 24, 27570 Bremerhaven, Germany
}

Received: 29 July 2008 - Published in Earth Syst. Sci. Data Discuss.: 22 September 2008

Revised: 1 December 2008 - Accepted: 23 December 2008 - Published: 12 January 2009

\begin{abstract}
On 22 May 1985 the first balloon-borne ozonesonde was successfully launched by the staff of Georg-Forster-Station $\left(70^{\circ} 46^{\prime} \mathrm{S}, 11^{\circ} 41^{\prime} \mathrm{E}\right)$. The subsequent weekly ozone soundings mark the beginning of a continuous investigation of the vertical ozone distribution in the southern hemisphere by Germany.

The measurements began the year the ozone hole was discovered. They significantly contribute to other measurements made prior to and following 1985 at other stations. The regular ozone soundings from 1985 until 1992 are a valuable reference data set since the chemical ozone loss became a significant feature in the southern polar stratosphere.

The balloon-borne soundings were performed at the upper air sounding facility of the neighbouring station Novolazarevskaya, just $2 \mathrm{~km}$ from Georg-Forster-Station. Until 1992, ozone soundings were taken without interruption. Thereafter, the ozone sounding program was moved to Neumayer-Station $\left(70^{\circ} 39^{\prime} \mathrm{S}, 8^{\circ} 15^{\prime} \mathrm{W}\right)$ $750 \mathrm{~km}$ further west.
\end{abstract}

\section{Data coverage and parameter measured}

Repository-Reference: doi:10.1594/PANGAEA.547983

Coverage: East: 11.8300; South: -70.7700;

Location Name: Georg-Forster-Station, Antarctica

Date/Time Start: 1985-05-22T05:19:00

Date/Time End: 1992-01-29T01:19:00

\begin{tabular}{|c|c|c|c|}
\hline Parameter & Short Name & Unit & Comment \\
\hline Altitude & Altitude & $\mathrm{m}$ & $\begin{array}{l}\text { height above mean } \\
\text { sea level }\end{array}$ \\
\hline Date/Time & Date/Time & & $\begin{array}{l}\text { universal time code } \\
\text { (UTC) }\end{array}$ \\
\hline Longitude & Longitude & & at launching point \\
\hline Latitude & Latitude & & at launching point \\
\hline Ozone, partial pressure & $\mathrm{O}_{3}$ & $\mathrm{mPa}$ & \\
\hline Pressure, at given altitude & PPPP & $\mathrm{hPa}$ & \\
\hline Temperature, air & TTT & $\operatorname{deg} C$ & \\
\hline Wind direction & dd & deg & \\
\hline Wind speed & $\mathrm{ff}$ & $\mathrm{m} / \mathrm{sec}$ & \\
\hline
\end{tabular}

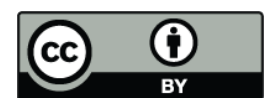

Correspondence to: G. König-Langlo (gert.koenig-langlo@awi.de)

\section{Introduction}

The first permanently operated German research base - later named Georg-Forster-Station - was established in 1976 in the Schirmacher Oasis at $70^{\circ} 46^{\prime} \mathrm{S}, 11^{\circ} 41^{\prime} \mathrm{E}$. The station was permanently used and operated as an annex to the Russian station Novolazarevskaya until 1987, and then as a German Antarctic station named after the German natural scientists, author and revolutionary Georg Forster (1754-1794) until 1993.

Long-term studies of magnetospheric-ionospheric processes, geophysical investigations, biological studies and sea ice observations using satellite imaging were performed.

The station became known to the international scientific community when the vertical extent of the "ozone hole" in the southern polar stratosphere was firstly recorded by regular balloon-borne ozone observations in 1985 (Gernandt, 1987a, b).

The ozone sounding programme was a major contribution of the Meteorological Service to the Antarctic research of the German Democratic Republic (GDR). The station was established as a long-term ozone-sonde observatory in cooperation with the Russian Arctic and Antarctic Research Institute (AARI) and the Aerological Observatory Lindenberg (AOL) in order to study the climatology of the ozone layer in

Published by Copernicus Publications. 
the southern polar stratosphere. The scientific and technical preparations were performed at AOL, where the training of personnel working at the station also took place.

The measurements began the year the ozone hole was discovered. They significantly contribute to other measurements made prior to and following 1985 at other stations. In 1985 these ozone soundings were the only record showing the change of vertical ozone distribution in the southern polar stratosphere in September and October. These results supplemented the strong negative trends in total ozone which had been observed at the British station Halley (Farman et al., 1985) for several years. Further studies focussed on understand the dynamical control of the chemical ozone loss in spring (Gernandt et al., 1989). For spring 1987 these investigations were extended by including balloon-borne observations from Halley, and the American Amundsen-Scott South Pole Station (Gernandt et al., 1995). The ozone data of Georg-Forster-Station were also compared with Arctic observations in order to qualitatively understand possible chemical ozone losses in the Arctic stratosphere (Müller et al., 1997).

The regular ozone soundings from 1985 until 1992 are a valuable reference data set after chemical ozone loss became a significant feature in the southern polar stratosphere.

\section{Instrumentation}

Since the end of 1974 balloon-borne electrochemical ozone sondes have been regularly launched, i.e. once or three times per week, at the Aerological Observatory Lindenberg $\left(52.22^{\circ} \mathrm{N}, 14.12^{\circ} \mathrm{E}\right)$ of the Meteorological Service of GDR. The ozone sensor was developed by Rönnebeck and Sonntag (1976) on the basis of the Brewer-Mast principle (Brewer, Milford, 1960). The sondes of the type OSE-2, OSM-2, OSR (since April 1981), OSE-3 (since September 1986) and OSE-4 (since August 1989) were manufactured in cooperation with the Scientific Instrument Laboratory of the Academy of Sciences in Berlin. Prototypes of the sonde took part in the International Ozone Sonde Intercomparisons at Hohenpeissenberg in 1970 (Attmannsbacher, Dütsch, 1970) and in 1978 (Attmannspacher, Dütsch, 1981).

The ozone sensors were adapted to the Russian balloonborne radiosonde system Meteorit/RKS-5 for data transmission, receiving and processing of ozone partial pressure. The standard data, temperature and humidity, were obtained from the radiosonde RKS-5. Pressure, wind direction and wind speed were derived from radar measurements of the ground station Meteorit tracking the balloon flight.

The ozone partial pressure measurements were achieved by a small electrically driven gas sampling pump which forces ambient air through a sensing solution of an electrochemical cell (Brewer-Mast principle) which generates an electrical current proportional to the mass flow rate of ozone.

For balloon-borne ozone profile measurements a pump correction has to be applied in order to compensate for
Table 1. Correction factor $C$ and standard deviation $S D$ as obtained by spectrometer measurements of column ozone and column ozone obtained by profile integration at Georg-Forster-Station for October 1987 to 1991 .

\begin{tabular}{llll}
\hline Year & number of profiles & $C$ & $S D$ \\
\hline 1987 & 10 & 1.087 & 0.376 \\
1988 & 6 & 0.930 & 0.097 \\
1989 & 3 & 0.894 & 0.146 \\
1990 & 8 & 1.129 & 0.153 \\
1991 & 7 & 1.038 & 0.389 \\
\hline
\end{tabular}

the decreasing pump efficiency with increasing height and changing air temperature. An inadequate pump correction and an erroneous estimate of residual ozone above the height of balloon burst may both contribute to the overall measurement error of the ozone profile. Usually an independent column ozone observation $X_{D}$ by spectrometer measurement is compared with the integrated column ozone $X_{S}$ between the ground level and the height of balloon burst plus an estimated residual ozone above that level to adjust the recorded profile values. The correction factor listed in Table 1 is

$C=X_{D} / X_{S}$

Systematic differences and random errors of the electrochemical ozone sonde, type OSR, has been estimated by analysing 20 tandem ozone soundings at the Aerological Observatory Lindenberg in 1982 (Feister, Grasnick and Peters, 1985). Random errors are at their maximum of about 10 to $13 \%$ in the troposphere and above $32 \mathrm{~km}$, and reach a minimum of 2 to $5 \%$ between 20 and $28 \mathrm{~km}$. The mean random error is $11.5 \%$ in the troposphere, $7 \%$ in the stratosphere beneath the ozone maximum height (ca. $22 \mathrm{~km}$ in Europe), and $5.6 \%$ above that height. Due to the lower temperature and different height distribution of the ozone the errors in Antarctica may differ from these findings.

\section{Dataset}

The dataset compiles 426 individual subsets of data, one for each sounding. Figure 1 presents an overview of the ozone measurements from the whole dataset.

The data were taken while the balloons were ascending. The soundings were terminated at the burst level of the balloons. The ascent velocity was about $5 \mathrm{~m} / \mathrm{s}$. During summertime - when the stratosphere was relatively warm - the balloons frequently reached levels above $30000 \mathrm{~m}$. During wintertime the low temperatures in the stratosphere (below $-80^{\circ} \mathrm{C}$ ) lead to lower burst heights. Regular launches were performed once per week and during spring (September, October) up to three soundings per week. Occasionally strong 


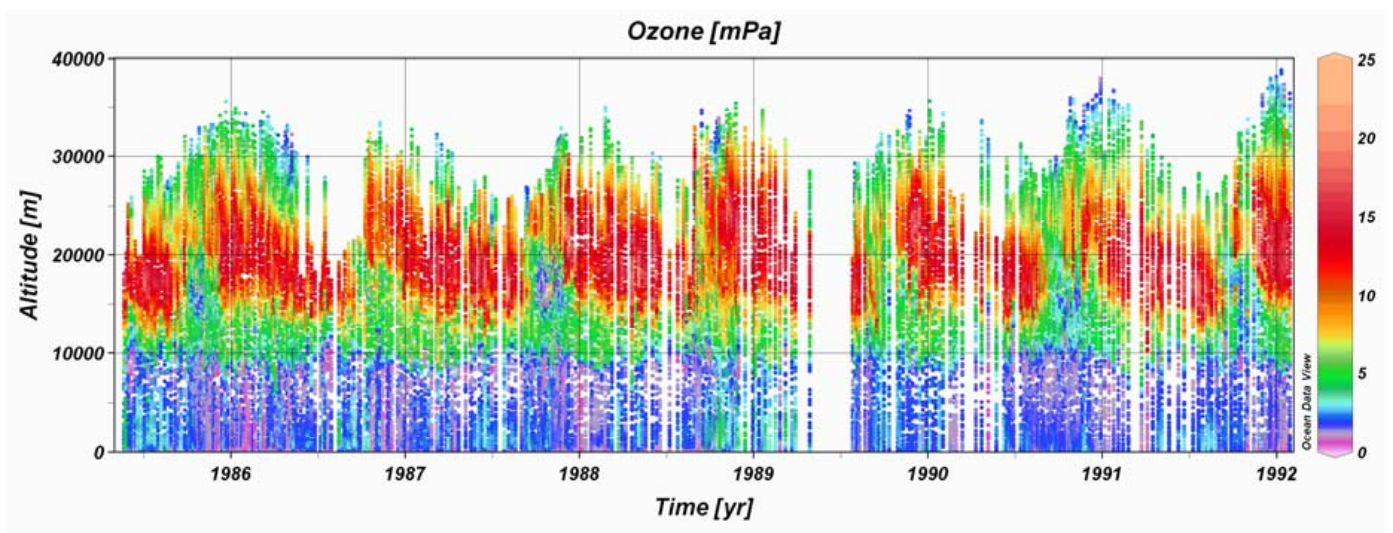

Figure 1. Time-height sections the annual ozone variation over Georg-Forster-Station.

winds or technical problems (1989) made the measurements impossible.

\subsection{Related datasets}

Related datasets which were used with the data from Georg-Forster-Station. The locations of the corresponding Antarctic stations are shown in Fig. 2:

Syowa, Antarctica, $\left(69^{\circ} 00^{\prime} \mathrm{S}, 39^{\circ} 35^{\prime} \mathrm{E}\right)$ :

Ozone soundings since 1966, these data are used as a very important reference for the pre-ozone hole period in the Dronning Maud Land region (Chubachi, 1984, Solomon et al. 2005, Gernandt et al., 1996).

Faraday, Antarctica, $\left(65^{\circ} 15^{\prime} \mathrm{S}, 64^{\circ} 16^{\prime} \mathrm{W}\right)$ :

A series of ozone flights was performed from March 1982 till April 1983. Individual flights do show indications of ozone depletion although it was not recognized at that time (Shanklin, 1985).

Halley, Antarctica, $\left(75^{\circ} 35^{\prime} \mathrm{S}, 26^{\circ} 34^{\prime} \mathrm{W}\right)$ :

Ozone soundings performed in 1987 were used for dynamical studies of ozone variations (Gernandt, 1995).

Amundsen-Scott South Pole Station, Antarctica $\left(90^{\circ} 00^{\prime} \mathrm{S},-\right)$ : Ozone soundings performed in 1987 were used for dynamical studies of ozone variations (Gernandt, 1995).

Koldewey-Station, Svalbard ( $\left.79^{\circ} 55^{\prime} \mathrm{N}, 11^{\circ} 52^{\prime} \mathrm{E}\right)$ :

Ozone soundings performed since October 1991 data are used for bipolar comparisons (Gernandt et al., 1998; Rex et al., 2000).

Neumayer-Station, Antarctica, $\left(70^{\circ} 39^{\prime} \mathrm{S}, 8^{\circ} 15^{\prime} \mathrm{W}\right)$ :

After January 1992 the ozone soundings at Georg-ForsterStation were continued at Neumayer-Station $750 \mathrm{~km}$ further west (König-Langlo et al., 2006). At Neumayer ECC 5A/6A

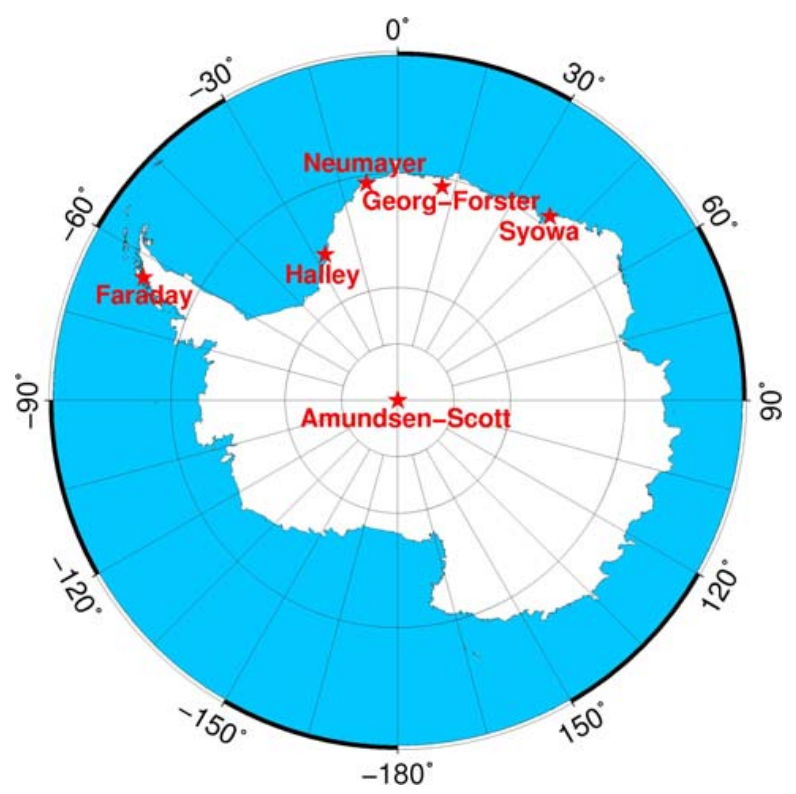

Figure 2. Location of Georg-Forster-Station and all other Antarctic stations with related datasets.

ozone sondes (VAISALA) were used. As the result of an intercomparison with TOMS data no correction factor was applied. The results of both stations are presented as one time series, see Fig. 3. It is the longest nearly continuously measured time series of balloon-borne ozone observations since the chemical ozone loss became a significant feature in the stratosphere.

The combined time series of both stations show the development of the stratospheric ozone layers from 1985 until now. In terms of balloon observations it is the longest and thus unique record since the "ozone hole" has been discovered. Height-dependent trend and forcing studies were performed for the combined time series of balloon-borne ozone soundings (Gernandt et al., 1998). 


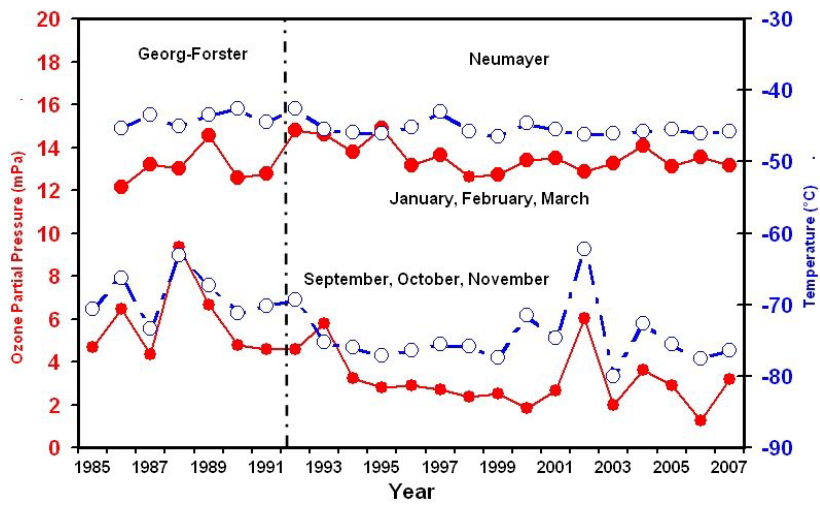

Figure 3. Time series of seasonal averaged ozone partial pressure $(\mathrm{mPa})(\mathrm{red})$ and temperature $\left({ }^{\circ} \mathrm{C}\right)$ (blue) from Georg-Forster-Station and Neumayer-Station at $70 \mathrm{hPa}$.

\section{Data access}

The whole data set is published at http://dx.doi.org/10.1594/ PANGAEA.547983. It contains the 426 doi-references of each single sounding. The whole dataset can be downloaded as one zipped file of tab-delimited textfiles. Each textfile includes all necessary metadata and a table containing all parameters of one sounding. No special software is needed to access the data. Special software is offered to convert or visualize the data, see http://pangaea.de/software/. Figure 1 can be taken as an example produced using ODV (Ocean Data View).

Acknowledgements. The ozone sounding programme at GeorgForster-Station was funded by the Meteorological Service of the GDR as a contribution to the East-German Antarctic research programme. The scientific supervision and technical preparations of the Antarctic observations were performed at the Aerological Observatory Lindenberg (since 1990 Meteorological Observatory of the German Weather Service (DWD)).

The ozone sounding programme was developed and performed in cooperation with the Russian Arctic and Antarctic Research Institute (AARI), which provided the balloon launching facilities and radiosonde ground station Meteorit at Novolazarevskaya.

Support was given by the Japanese National Institute of Polar Research, which delivered special balloons to perform the ozone soundings during the winter period 1988.

Peter Plessing from the Meteorological Main Observatory of the Meteorological Service started the regular ozone soundings on 22 May 1985 and stayed for the first winter at the Georg-ForsterStation. Special thanks are given to him and to all following wintering over personal at Georg-Forster-Station and their Russian colleagues at Novolazarevskaya who performed and supported the ozone soundings from 1985 until 1992.

Edited by: D. Carlson

\section{References}

Attmanspacher, W. and Dütsch, H. U.: International Ozone Sonde Intercomparison at the Observarory Hohenpeienberg, 19 January-5 February 1970, Rep. 120, Deutscher Wetterdienst, Offenbach, Germany, 85 pp., 1970.

Attmannspacher, W. and Dütsch, H. U.: 2nd International ozone sonde intercomparison at the Observarory Hohenpeissenberg 520 April 1978, Ber. Dtsch. Wetterdienstes, 157, 1, 1981.

Brewer, A. and Milford, J.: The Oxford-Kew ozone sonde, Proc. Roy. Soc. London, Ser. A, 256, 470-495, 1960.

Chubachi, S.: Preliminary result of ozone observations at Syowa station from February 1982 to January 1983, Mem. Natl. Inst. Polar Res., Spec. Issue No. 34, Proc. Sixth Annual Symp. Polar Meteorology and Glaciology, 13-19, Natl. Inst. of Polar Res., Tokyo, Japan, 1984.

Feister, U., Grasnick, K. H., and Peters, G.: Performance of the Electrochemical Ozone Sonde OSR. Pageoph., 123, 422-440, 1985.

Farman, J., Gardiner, B., and Shanklin, J. D.: Large losses of total ozone in Antarctica reveal seasonal $\mathrm{ClO}_{\mathrm{x}} / \mathrm{NO}_{\mathrm{x}}$ interaction, Nature, 315, 207-210, 1985.

Gernandt, H.: The vertical ozone distribution above the GDR research base, Antarctica, 1985, Geophys. Res. Lett., 14(1), 84-86, 1987a.

Gernandt, H., Plessing, P., Feister, U., Peters, G., and Pisch, H.: A preliminary result of the ozone observation at GDR research base $\left(70.77^{\circ} \mathrm{S}, 11.85^{\circ} \mathrm{E}\right)$ from May to December 1985 , Memoirs of National Institute of Polar Research, Tokyo, Special Issue, 48, 256-271, 1987b.

Gernandt, H., Gloede, P., Feister, U., Peters, G., and Thees, B.: Vertical distributions of ozone in the lower stratosphere over Antarctica and their relations to the spring depletion. Planet. Space Sci., 37(8), 915-933, 1989.

Gernandt, H.: The vertical ozone distribution in the southern stratosphere, in: Scientific investigations of the Schirmacher Oasis and its surroundings, edited by: Bormann, P. and Fritzsche, D., Petermanns Geographische Mitteilungen, Ergänzungsheft 289, Justus Perthes Verlag Gotha, 361-373, 1995.

Gernandt, H., Herber, A., Gathen, P. von der, Rex, M., Rinke, A., Wessel, S., and Kaneto, S.: Variability of ozone and aerosols in the polar atmosphere, Mem. Natl. Inst. Polar Res., Spec. Issue, 51, 189-215, 1996.

Gernandt, H., Herber, A., Kaneto, S., and von der Gathen, P.: Ozone variation in the southern polar stratosphere, Mem. Natl. Inst. Polar Res., Spec. Issue, 52, 68-88, 1998.

König-Langlo, G. and Gernandt, H.: 20 Jahre Ozonsondierungen an den deutschen Antarktisstationen Georg-Forster und Neumayer, Ozonbulletin des Deutschen Wetterdienstes, Ausgabe Nr. 113, http://hdl.handle.net/10013/epic.25892, 2006.

MacDowall, J. and Smith, J. A.: Ozone soundings, The Royal Society I.G.Y. expedition, Halley Bay 1955-1959, Vol. III, 98-110, 1961.

Müller, R., Crutzen, P. J., Grooß, J.-U., Brühl, C., Russell, J. M., Gernandt, H., McKenna, D. S., and Tuck, A. F..: Severe chemical ozone loss in the Arctic during the winter of 1995-1996, Nature, 389, 709-712, 1997.

Rex, M., Dethloff, K., Handorf, D., Herber, A., Lehmann, R., Neuber, R., Notholt, J., Rinke, A., von der Gathen, P., Weisheimer, 
A., and Gernandt, H.: Arctic and Antarctic ozone layer observations: chemical and dynamical aspects of variability and longterm changes in the polar stratosphere, Polar Res., 19(2), 193204, 2000.

Rönnebeck, K. and Sonntag, D.: Eine weiterentwickelte elektrochemische Ozonradiosonde, Z.f. Meteor., Bd. 26, 15-19, 1976.
Shanklin, J. D.: Balloon-borne ozonesonde flights made from Faraday station, Br. Antarct Surv Bull, 69, 1-21, 1985.

Solomon S., Portmann, R. W., Sasaki, T., Hofmann, D. J., and Thompson. D. W. J.: Four decades of ozonesonde measurements over Antarctica, J. Geophys. Res., 110, D21311, doi:10.1029/2005JD005917, 2005. 